Sādhanā Vol. 40, Part 4, June 2015, pp. 1343-1359. (C) Indian Academy of Sciences

\title{
The effect of fly ash to self-compactability of pumice aggregate lightweight concrete
}

\author{
MURAT KURT $^{1}$, ABDULKADIR CÜNEYT AYDIN ${ }^{2, *}$, \\ MUHAMMED SAID GÜL ${ }^{2}$, RÜSTEM GÜL ${ }^{2}$ and \\ TÜRKAY KOTAN ${ }^{3}$
}

\author{
${ }^{1}$ Pasinler Vocational School, Construction Department, Atatürk University, \\ 25300 Erzurum, Turkey \\ ${ }^{2}$ Engineering Faculty, Department of Civil Engineering, Atatürk University, \\ 25240 Erzurum, Turkey \\ ${ }^{3}$ Engineering Faculty, Department of Civil Engineering, Bayburt University, \\ 69000 Bayburt, Turkey \\ e-mail: acaydin@atauni.edu.tr
}

MS received 3 July 2014; revised 2 December 2014; accepted 8 December 2014

\begin{abstract}
This paper presents the results of an experimental study on the effects of fly ash, different water/(cement + mineral additive) ratios and pumice aggregates to some physical and mechanical properties of self-compacting lightweight aggregate concrete. In this study, pumice had been used as lightweight aggregates. Several properties of self-compacting pumice aggregate lightweight concretes like the unit weight, flow diameter, T50 time, flow diameter after an hour, V-funnel time, and L-box tests, 7, 28, 90 and 180-day compressive strength, 28-day splitting tensile strength, dry unit weight, water absorption, thermal conductivity and ultrasonic pulse velocity tests were investigated. For this purpose, 18 series of concrete samples were prepared in two groups. Pumice aggregate was used as a replacement of natural aggregate, at the levels of $0,20,40,60,80$, and $100 \%$ by volume. Furthermore, a second series of $100 \%$ pumice aggregate was used for the production of self-compacting lightweight aggregate concrete with constant $\mathrm{w} /(\mathrm{c}+\mathrm{m})$ ratios as $0.35,0.40$, and 0.45 by weight. The flow diameters, T50 times, paste volumes, 28-day compressive strengths, dry unit weights and thermal conductivities of self-compacting lightweight aggregate concrete were obtained in the range of $600-800 \mathrm{~mm}, 2-8 \mathrm{~s}, 471-572 \mathrm{lt} / \mathrm{m}^{3}, 9.2-53.26$ $\mathrm{MPa}, 839-2156 \mathrm{~kg} / \mathrm{m}^{3}$ and $0.321-1.508 \mathrm{~W} / \mathrm{mk}$, respectively, which satisfies not only
\end{abstract}

${ }^{*}$ For correspondence 
the strength requirement of semi-structural lightweight concrete but also the flowing ability requirements and thermal conductivity requirements of self-compacting lightweight aggregate concrete.

Keywords. Lightweight aggregate concrete; self-compacting concrete; pumice; fly ash.

\section{Introduction}

Concrete is a multiphase exceedingly complex heterogeneous material and one of the principal materials for structures. However, the heterogeneous structure of concrete results in some undesirable effects. The heterogeneity and properties of concrete is mostly concerned with the hydration. Hydration, the chemical reaction between water and ingredients of cement, is one of the most important properties of its strength gain process. This property of hydration caused volume change of hydrated cement, varying hydration rate through the concrete and time dependency of strength gain. One of the main effects of strength gain is the improved mechanical properties of concrete. The mechanical properties of cement based material is needed by designers for stiffness and deflections evaluation and is a fundamental property required for the proper modelling of its constitutive behaviour and for its proper use in various structural applications. For this reason, determination of mechanical properties of concrete has become very important for a design point of view. However, due to the economic considerations, there is strong demand on natural resource usage. Moreover, when weights of the structures are considered, not only natural light weight aggregates but also artificial light materials, such as gas concrete, are used. Incorporation of natural/artificial resources in concrete brings environmental, economic and/or technological benefits (Gül et al 2007; Aydın et al 2006, 2007, 2008, 2010; Aydın 2007; Aydın \& Gül 2007; Düzgün et al 2005; Tortum et al 2005; Oğuz \& Aydın 2003; Hasar et al 2009, 2010; Türkmen et al 2010).

Self-compacting concrete (SCC) is considered as a concrete which can be placed and compacted under its self-weight with little or no vibration effort, and, which is at the same time cohesive enough to be handled without segregation or bleeding (Boukendakdji et al 2009). SCC was originally developed at the University of Tokyo, Japan during the year 1986 by Prof. Okamura and his team to improve the quality of construction and also to overcome the problems of defective workmanship (Sukumar et al 2008). It is used to facilitate and ensure proper filling and good structural performance of restricted areas and heavily reinforced structural members. SCC can also provide a better working environment by eliminating the vibration noise (Siddique 2011). Self-compacting lightweight aggregate concrete (SCLC) is a kind of high-performance concrete developed from self-compacting concrete (SCC). SCLC combines the favourable properties of lightweight aggregate concrete (LWAC) and SCC, needs no external vibration, and can spread into place, fill the formwork and encapsulate reinforcement without any bleeding or segregation (Wua et al 2009). On the other hand, the use of chemical admixtures is always necessary when producing SCC in order to increase the workability and reduce the segregation. The content of coarse aggregate and the water to binder ratio in SCC are lower than those of normal concrete. Therefore, SCC contains large amounts of fine particles such as blast-furnace slag, fly ash and lime powder in order to avoid gravity segregation of larger particles in the fresh mix (Khatib 2008; Kurt 2009).

Pumice is a natural material of volcanic origin produced by the release of gases during the solidification of lava, and it has been used as the aggregate in the production of lightweight concrete in many countries of the world. So far, the use of pumice was dependent on the availability 
and limited to the countries where it is locally available or easily imported. Approximately, 7.4 billion $\mathrm{m}^{3}(40 \%)$ of the total 18 billion $\mathrm{m}^{3}$ of pumice reserve is located in Turkey (Kotan \& Gül 2010). So, the use of pumice as aggregate or mineral additive in production of self-compacting concrete may be a good approach for the production of lightweight, easy workable, economic and environmentalist concrete.

There has been an increase in using self-compacting concrete (SCC) in recent years and a number of papers have been published (Khatib 2008). However, there is very little documentation on self-compacting lightweight aggregate concrete, which has superior advantages as using natural materials, lightness and easy workability. Thus, a study was performed following the literature information given above. For this purpose, experimental studies were carried out in two base groups. In the first group, concrete specimens with three different water/(cement + mineral additive) portions were prepared by using volcanic originated pumice aggregate at $100 \%$. In the second group, concrete specimens with constant water/(cement + mineral additive) portions and complemented by blast furnace slag and fly ash instead of cement were produced by replacing pumice five different ratios instead of the normal aggregate. Then, some physical and mechanical properties as workability, unit weight, compressive and splitting tensile strength, UPV and thermal conductivity of self-compacting concrete were investigated.

\section{Materials and experimental study}

\subsection{Materials}

In this study, CEM I $42.5 \mathrm{~N}$ and F class fly ash were used. This fly ash is accepted F class fly ash, because $\mathrm{CaO}$ content is less than $10 \%$. The pumice aggregate supplied from volcanic slug furnace at Demirdöven region of Pasinler/Erzurum was used as lightweight aggregate. Chemical properties of cement, fly ash and pumice aggregate are given in table 1; physical and mechanical properties of them are given in table 2. For the natural aggregates, the natural sand from Aras River and crushed gravel aggregates supplied at Yağan region of Erzurum were used as normal

Table 1. Chemical properties of cement, fly ash and pumice aggregate.

\begin{tabular}{lccc}
\hline Component & Portland cement $(\%)$ & Fly ash $(\%)$ & Pumice aggregate (\%) \\
\hline $\mathrm{SiO}_{2}$ & 20.79 & 47.50 & 69.78 \\
$\mathrm{Al}_{2} \mathrm{O}_{3}$ & 5.17 & 15.95 & 11.16 \\
$\mathrm{Fe}_{2} \mathrm{O}_{3}$ & 3.43 & 16.60 & 2.11 \\
$\mathrm{CaO}$ & 60.29 & 6.60 & 2.47 \\
$\mathrm{MgO}$ & 3.03 & 4.65 & 0.60 \\
$\mathrm{SO}_{3}$ & 3.12 & 3.94 & 0.06 \\
$\mathrm{Na}_{2} \mathrm{O}$ & 0.41 & 1.74 & 4.33 \\
$\mathrm{~K}_{2} \mathrm{O}$ & 0.66 & 1.96 & 2.87 \\
$\mathrm{CI}-$ & 0.0251 & - & 0.0496 \\
$\mathrm{Free} \mathrm{CaO}$ & 0.34 & 0.56 & - \\
$\mathrm{Na} 2 \mathrm{O}+\mathrm{K}$ & $\mathrm{O}$ & 3.70 & - \\
$\mathrm{Insoluble} \mathrm{matter}$ & - & - & - \\
Ignition loss & 2.47 & - & 4.66 \\
Undetermined & 2.79 & - & - \\
\hline
\end{tabular}


Table 2. Physical and mechanical properties of Portland cement and fly ash.

\begin{tabular}{lccc}
\hline Properties & Portland cement & Fly ash \\
\hline Specific gravity $\left(\mathrm{g} / \mathrm{cm}^{3}\right)$ & 3.13 & 2.05 \\
Specific surface $\left(\mathrm{cm}^{2} / \mathrm{g}\right)$ & 3751 & 3500 \\
Retained on the sieve of $0.09 \mathrm{~mm}$ & 1 & - \\
Initial set (hour-minute) & $2 \mathrm{~h}-38 \mathrm{~min}$ & - \\
Final set (hour-minute) & $3 \mathrm{~h}-15 \mathrm{~min}$ & - \\
Volume expansion (Le Chatelier, $\mathrm{mm})$ & & 2 & - \\
Compressive strength $(\mathrm{MPa})$ & $2^{\text {th }}$ day & 23.6 & - \\
& $7^{\text {th }}$ day & 37.9 & - \\
\hline
\end{tabular}

aggregate. The grading curves of pumice and normal aggregates used in experiments were presented in figure 1. The specific gravity factor (SGF) incorporates compensation for absorption of free water by the pumice aggregates, but it is used in exactly the same way to calculate volume relationship. The specific gravity factor of lightweight aggregate for 10 min was used in calculation of effective volume for $1 \mathrm{~m}^{3}$ concrete; the specific gravity and moisture percentages of normal aggregate were also used.

Also, specific gravity factor, specific gravity (SG) and water absorption values of normal and lightweight aggregate for different grain sizes were given in table 3 . Besides, the ratio of fine aggregate was determined as $50 \%$ and $60 \%$ in the experiments to ensure the condition of selfcompacting of fresh concrete.

As a result of this adjustment, aggregate ratios of grain class were determined as $30 \%$ and $42 \%$ for $0-2 \mathrm{~mm}, 20 \%$ and $18 \%$ for $2-4 \mathrm{~mm}, 35 \%$ and $20 \%$ for $4-8 \mathrm{~mm}, 15 \%$ and $20 \%$ for $8-16 \mathrm{~mm}$ in, I and II Group of experiments, respectively. The fineness modules were 3.86 for the I group and 3.50 for the II group of mixes. Furthermore, a third generation modified polycarboxylatebased hyper-plasticizer was used in the concrete mix to provide viscosity and an air entraining admixture was used to reduce the risk of segregation and to increase the cohesion in some cases.

\subsection{Experimental study}

This study was conducted in two groups. In the first-group of experiments, pumice at $100 \%$ was used as the aggregate in concrete. SCC samples were produced at three different $\mathrm{w} /(\mathrm{c}+\mathrm{m})$ ratios $(35,40,45 \%)$ and three different fly ash ratios $(20,30,40 \%)$. In the second group of experiments, pumice at five different ratios $(20,40,60,80,100 \%)$ was used instead of normal
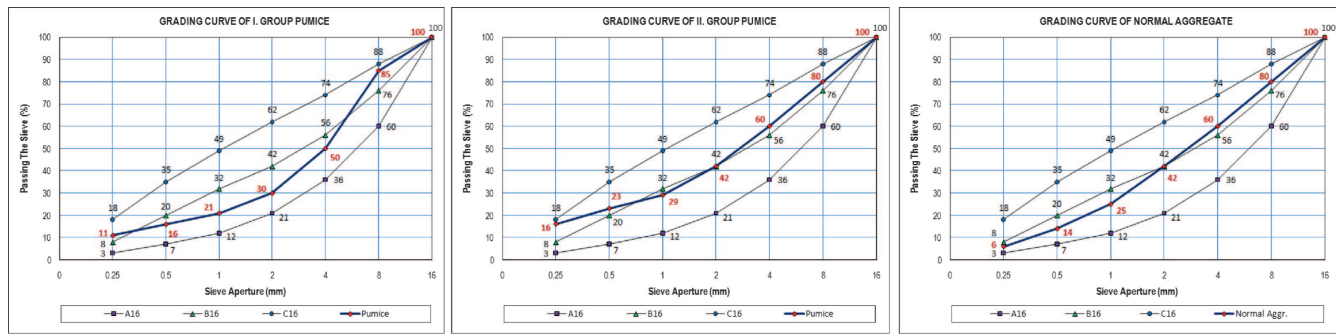

Figure 1. Grading curves of pumice and normal aggregates used in I and II group experiments. 
Table 3. The specific gravity factor, specific gravity and water absorption values of aggregates (according to TS EN 1097).

\begin{tabular}{|c|c|c|c|}
\hline \multirow[b]{2}{*}{ Grain size } & \multirow{2}{*}{$\begin{array}{l}\text { Lightweight aggregate } \\
\text { SGF }\end{array}$} & \multicolumn{2}{|c|}{ Normal aggregate } \\
\hline & & $\overline{\mathrm{SG}}$ & Water absorption (\%) \\
\hline $0 / 2$ & 1.68 & 2.41 & 6.48 \\
\hline $2 / 4$ & 1.18 & 2.60 & 1.69 \\
\hline $4 / 8$ & 0.98 & 2.59 & 2.92 \\
\hline $8 / 16$ & 0.92 & 2.61 & 2.24 \\
\hline
\end{tabular}

aggregate for every grain grade. The $w /(\mathrm{c}+\mathrm{m})$ ratio was constant as 0.30 and fly ash at $40 \%$ of cement weight was replaced instead of cement. Hyper plasticizer and air entraining agents were used in SCC mixes to increase workability, to decrease segregation and bleeding. Thus, fresh and hardened concrete properties as workability, unit weight, and compressive strength, splitting tensile strength, UPV and thermal conductivity of produced normal, structural semi-lightweight, structural lightweight and lightweight SCC were investigated. The concrete mixture proportions are given in tables 4 and 5 for I group and II group concrete samples, respectively.

\subsection{Workability tests}

The self-compacting ability of SCC may be defined by three parameters; filling ability, resistance to segregation and passing ability (EFNARC 2002). Haist and his co-workers (2003) proposed three mix proportions for SCLC and assessed their self-compacting properties by the slump flow,

Table 4. Concrete mixture proportions of the I group samples and control samples (CS).

\begin{tabular}{|c|c|c|c|c|c|c|c|c|c|c|c|c|c|}
\hline \multicolumn{2}{|c|}{ Components } & CS1 & $\mathrm{CS} 2$ & $\mathrm{CS} 3$ & FA1 & FA2 & FA3 & FA4 & FA5 & FA6 & FA7 & FA8 & FA9 \\
\hline \multicolumn{2}{|l|}{ Cement $\left(\mathrm{kg} / \mathrm{m}^{3}\right)$} & 550 & 550 & 550 & 440 & 440 & 440 & 385 & 385 & 385 & 330 & 330 & 330 \\
\hline \multicolumn{2}{|l|}{ Water $\left(\mathrm{kg} / \mathrm{m}^{3}\right)$} & 193 & 220 & 248 & 193 & 220 & 248 & 193 & 220 & 248 & 193 & 220 & 248 \\
\hline \multicolumn{2}{|l|}{ Fly ash $\left(\mathrm{kg} / \mathrm{m}^{3}\right)$} & & & & 98 & 98 & 98 & 152 & 152 & 152 & 208 & 208 & 208 \\
\hline \multicolumn{2}{|c|}{ Super plasticizer $\left(\mathrm{kg} / \mathrm{m}^{3}\right)$} & 11 & 11 & 11 & 11 & 11 & 11 & 11 & 11 & 11 & 11 & 11 & 11 \\
\hline \multicolumn{2}{|c|}{ Air entraining $\left(\mathrm{kg} / \mathrm{m}^{3}\right)$} & 1 & 1 & 1 & 1 & 1 & 1 & 1 & 1 & 1 & 1 & 1 & 1 \\
\hline \multirow[t]{4}{*}{ Pumice $\left(\mathrm{kg} / \mathrm{m}^{3}\right)$} & $0 / 2$ & 262 & 248 & 235 & 266 & 251 & 236 & 261 & 246 & 232 & 256 & 241 & 227 \\
\hline & $2 / 4$ & 123 & 116 & 110 & 118 & 112 & 105 & 161 & 110 & 103 & 114 & 108 & 101 \\
\hline & $4 / 8$ & 178 & 169 & 160 & 172 & 163 & 153 & 169 & 160 & 150 & 166 & 156 & 147 \\
\hline & $8 / 16$ & 72 & 68 & 64 & 69 & 65 & 62 & 68 & 64 & 60 & 67 & 63 & 59 \\
\hline \multicolumn{2}{|c|}{ Theor. unit weight** $\left(\mathrm{kg} / \mathrm{m}^{3}\right)$} & 1390 & 1384 & 1378 & 1367 & 1361 & 1355 & 1356 & 1350 & 1344 & 1345 & 1339 & 1333 \\
\hline \multicolumn{2}{|c|}{ Powder quantity $\left(\mathrm{kg} / \mathrm{m}^{3}\right)$} & 550 & 550 & 550 & 550 & 550 & 550 & 550 & 550 & 550 & 550 & 550 & 550 \\
\hline \multicolumn{2}{|c|}{ Paste volume $\left(\mathrm{lt} / \mathrm{m}^{3}\right)$} & 480 & 507 & 535 & 498 & 526 & 553 & 507 & 535 & 562 & 517 & 544 & 572 \\
\hline \multicolumn{14}{|l|}{ Design parameters } \\
\hline \multicolumn{2}{|c|}{$\mathrm{w} /(\mathrm{c}+\mathrm{m})($ weight $)$} & 0.35 & 0.40 & 0.45 & 0.35 & 0.40 & 0.45 & 0.35 & 0.40 & 0.45 & 0.35 & 0.40 & 0.45 \\
\hline \multicolumn{2}{|c|}{$\mathrm{w} /(\mathrm{c}+\mathrm{m})$ (volume) } & $1.10^{*}$ & 1.25 & 1.41 & 0.99 & 1.13 & 1.27 & 0.95 & 1.08 & 1.22 & 0.90 & 1.03 & 1.16 \\
\hline \multicolumn{2}{|c|}{ Mineral admixture (Cem \%) } & 0 & 0 & 0 & 20 & 20 & 20 & 30 & 30 & 30 & 40 & 40 & 40 \\
\hline \multicolumn{2}{|c|}{ Sand/fine ag. (weight) } & 1.54 & 1.54 & 1.54 & 1.59 & 1.59 & 1.59 & 1.59 & 1.59 & 1.59 & 1.59 & 1.59 & 1.59 \\
\hline \multicolumn{2}{|c|}{ Fine ag./aggregate (volume) } & 0.50 & 0.50 & 0.50 & 0.50 & 0.50 & 0.50 & 0.50 & 0.50 & 0.50 & 0.50 & 0.50 & 0.50 \\
\hline
\end{tabular}


Table 5. Concrete mixture proportions of the II group samples.

\begin{tabular}{|c|c|c|c|c|c|c|c|}
\hline \multicolumn{2}{|c|}{ Components } & FANP100 & FANP80 & FANP60 & FANP40 & FANP20 & FANP0 \\
\hline \multicolumn{2}{|l|}{ Cement $\left(\mathrm{kg} / \mathrm{m}^{3}\right)$} & 375 & 375 & 375 & 375 & 375 & 375 \\
\hline \multicolumn{2}{|l|}{ Water $\left(\mathrm{kg} / \mathrm{m}^{3}\right)$} & 188 & 191 & 195 & 198 & 201 & 204 \\
\hline \multicolumn{2}{|l|}{ Fly ash $\left(\mathrm{kg} / \mathrm{m}^{3}\right)$} & 231 & 225 & 225 & 222 & 219 & 216 \\
\hline \multicolumn{2}{|c|}{ Super plasticizer $\left(\mathrm{kg} / \mathrm{m}^{3}\right)$} & 13 & 13 & 13 & 13 & 13 & 13 \\
\hline \multirow[t]{4}{*}{ pumice $\left(\mathrm{kg} / \mathrm{m}^{3}\right)$} & $0 / 2$ & 392 & 314 & 235 & 157 & 78 & 0 \\
\hline & $2 / 4$ & 112 & 90 & 67 & 45 & 22 & 0 \\
\hline & $4 / 8$ & 104 & 83 & 62 & 41 & 21 & 0 \\
\hline & $8 / 16$ & 97 & 78 & 58 & 39 & 19 & 0 \\
\hline \multirow[t]{4}{*}{ Normal $\left(\mathrm{kg} / \mathrm{m}^{3}\right)$} & $0 / 2$ & 0 & 119 & 238 & 356 & 475 & 594 \\
\hline & $2 / 4$ & 0 & 49 & 98 & 147 & 196 & 245 \\
\hline & $4 / 8$ & 0 & 56 & 111 & 167 & 222 & 278 \\
\hline & $8 / 16$ & 0 & 56 & 112 & 168 & 224 & 280 \\
\hline \multicolumn{2}{|c|}{ Theoretical unit weight } & 1512 & 1650 & 1789 & 1927 & 2066 & 2204 \\
\hline \multicolumn{2}{|c|}{ Powder quantity $\left(\mathrm{kg} / \mathrm{m}^{3}\right)$} & 625 & 625 & 625 & 625 & 625 & 625 \\
\hline \multicolumn{2}{|c|}{ Paste volume $\left(\mathrm{lt} / \mathrm{m}^{3}\right)$} & 471 & 471 & 471 & 471 & 471 & 471 \\
\hline \multicolumn{8}{|l|}{ Design parameters } \\
\hline \multicolumn{2}{|l|}{$\mathrm{w} /(\mathrm{c}+\mathrm{m})$ (weight) } & 0.30 & 0.30 & 0.30 & 0.30 & 0.30 & 0.30 \\
\hline \multicolumn{2}{|c|}{$\mathrm{w} /(\mathrm{c}+\mathrm{m})($ volume $)$} & 0.81 & 0.83 & 0.78 & 0.78 & 0.78 & 0.78 \\
\hline \multicolumn{2}{|c|}{ Sand/Fine ag. (weight) } & 2.51 & 2.10 & 1.86 & 1.70 & 1.59 & 1.50 \\
\hline \multicolumn{2}{|c|}{ Fine ag./aggregate (volume) } & 0.40 & 0.40 & 0.40 & 0.40 & 0.40 & 0.40 \\
\hline
\end{tabular}

J-ring, V-funnel, and L-box tests. It has been found that, compared with SCC, there is no significant difference in the mix proportion design except for the aggregate used (Wua et al 2009). To determine fluidity and workability properties of SCC, the V-funnel tests were performed to have information about flowing ability and viscosity with flow diameter and time of fresh concrete.

Besides, the L-box tests were made to determine the passing ability from narrow sections of fresh concrete. These fresh concrete tests were conducted according to standards of (EFNARC 2002), prepared by the European Working Group on Self-Compacting Concrete. Furthermore, to produce proper self-compacting mixes, several preliminary trials on self-compacting pumice concrete were carried out (figure 2).

For each mixture, the flow diameter, time to flow a diameter of $50 \mathrm{~cm}\left(\mathrm{~T}_{50}\right.$ time), flow diameter after one hour, V-funnel flow time, V-funnel times delayed 5 min, L-box ratio, air temperature and the unit weight of fresh concrete were measured. The details of the fresh concrete tests for SCC were given elsewhere (Wua et al 2009; EFNARC 2002, etc.). The V-funnel flow test is to

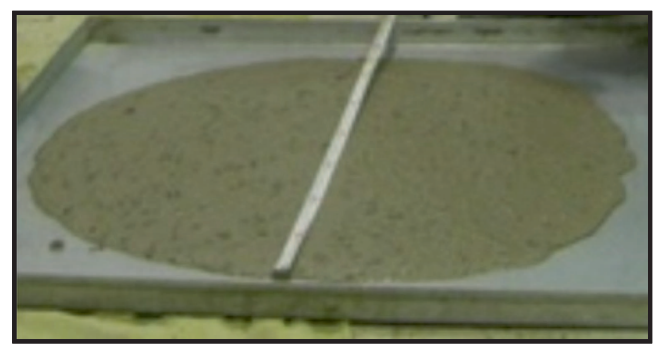

Figure 2. Slump flow test. 


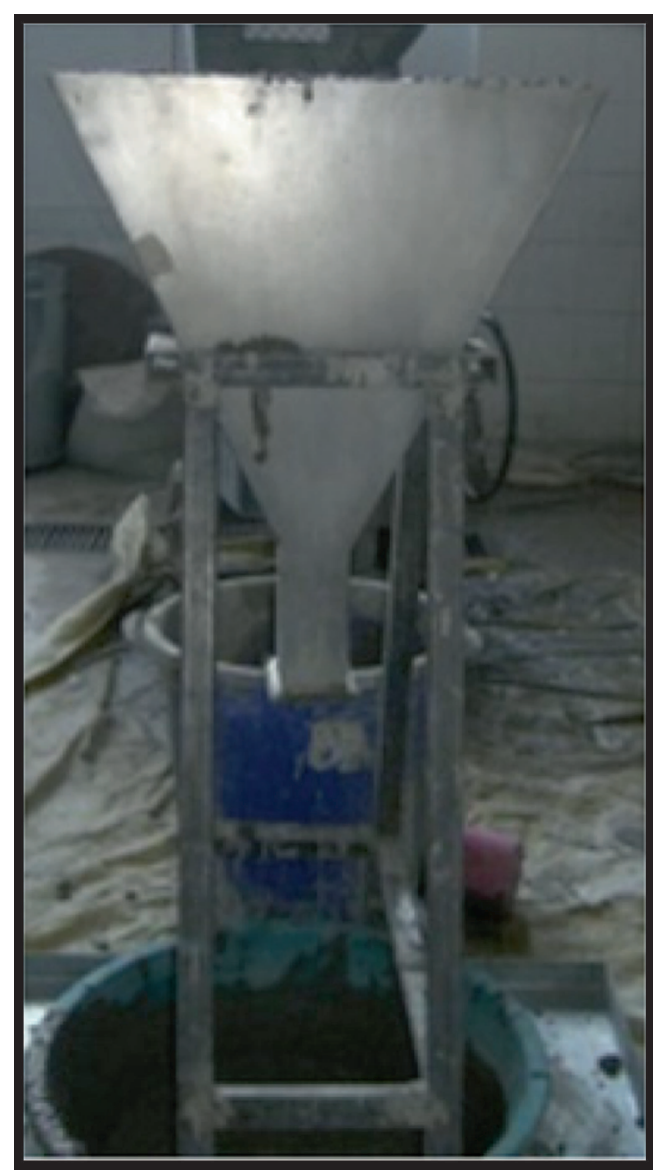

Figure 3. V-funnel test.

evaluate the fluidity of SCLC and the ability for SCLC to change its path and to pass through a constricted area. For this test, the V-funnel apparatus is shown in figure 3, the total time for

Table 6. The results of fresh concrete experiments for I group mixture.

\begin{tabular}{|c|c|c|c|c|c|c|c|c|c|c|c|c|c|}
\hline Mixtures & & CS1 & CS 2 & CS 3 & FA1 & FA2 & FA3 & FA4 & FA5 & FA6 & FA7 & FA8 & FA9 \\
\hline Flow diameter & $\mathrm{mm}$ & 600 & 640 & 650 & 660 & 690 & 700 & 680 & 720 & 730 & 690 & 730 & 740 \\
\hline T50 flow time & $\mathrm{s}$ & 7 & 6 & 5 & 5 & 4 & 4 & 4 & 4 & 3 & 4 & 3 & 3 \\
\hline Flow diameter after $1 \mathrm{~h}$ & $\mathrm{~mm}$ & 550 & 580 & 600 & 620 & 650 & 670 & 650 & 690 & 710 & 670 & 710 & 730 \\
\hline V-funnel flow time & $\mathrm{s}$ & 14 & 11 & 9 & 12 & 9 & 11 & 10 & 8 & 10 & 9 & 7 & 9 \\
\hline V-funnel time delayed $5 \mathrm{~min}$ & $\mathrm{~s}$ & 17 & 15 & 14 & 16 & 12 & 16 & 13 & 10 & 14 & 12 & 9 & 13 \\
\hline L-box ratio & $\mathrm{h}_{1} / \mathrm{h}_{2}$ & 0.81 & 0.88 & 0.88 & 0.81 & 0.88 & 0.88 & 0.81 & 0.93 & 0.93 & 0.88 & 0.88 & 0.93 \\
\hline $\begin{array}{l}\text { Unit weight of fresh } \\
\text { concrete }\end{array}$ & $\mathrm{kg} / \mathrm{m}^{3}$ & 1185 & 1175 & 1160 & 1172 & 1163 & 1154 & 1169 & 1160 & 1151 & 1164 & 1158 & 1147 \\
\hline Ambient temperature & ${ }^{\circ} \mathrm{C}$ & 18 & 18 & 19 & 23 & 22 & 24 & 23 & 24 & 22 & 18 & 25 & 25 \\
\hline
\end{tabular}


Table 7. The results of fresh concrete experiments for II group mixture.

\begin{tabular}{lccccccc}
\hline \multicolumn{1}{c}{ Mixtures } & & FANP100 & FANP80 & FANP60 & FANP40 & FANP20 & FANP0 \\
\hline Flow diameter & $\mathrm{mm}$ & 650 & 670 & 730 & 750 & 760 & 800 \\
T50 flow time & $\mathrm{s}$ & 8 & 7 & 4 & 4 & 3 & 2 \\
V-funnel flow time & $\mathrm{s}$ & 21 & 14 & 12 & 11 & 10 & 8 \\
V-funnel time delayed 5 min & $\mathrm{s}$ & Bloke & 20 & 16 & 14 & 11 & 9 \\
L-box ratio & $\mathrm{h}_{1} / \mathrm{h}_{2}$ & 0.77 & 0.81 & 0.88 & 0.93 & 0.93 & 0.93 \\
Unit weight of fresh concrete & $\mathrm{kg} / \mathrm{m}^{3}$ & 1357 & 1500 & 1712 & 1858 & 2074 & 2303 \\
Ambient temperature & ${ }^{\circ} \mathrm{C}$ & 16 & 18 & 17 & 16 & 17 & 18 \\
\hline
\end{tabular}

SCLC to flow through the V-funnel was measured. According to EFNARC (EFNARC 2002; Hasar et al 2010), for class $1 \mathrm{SCC} \mathrm{T}_{\mathrm{V}}$ is smaller than $8 \mathrm{~s}$ and for class $2 \mathrm{SCC} \mathrm{T}_{\mathrm{v}}$ is $9-25 \mathrm{~s}$ (Wua et al 2009). The measured values of $T_{\mathrm{V}}$ and $T_{50}$ time are presented in tables 6 and 7 .

The L-box test is used to evaluate the fluidity of SCLC and the ability for SCLC to pass through steel bars (Wua et al 2009). The L-box consists of a "chimney" section and a "channel" section as shown in figure 4 . With the L-box, the height of concrete in the chimney, $\mathrm{h}_{1}$, the height of concrete in the channel section, $\mathrm{h}_{2}$, and the time for SCLC to reach $400 \mathrm{~mm}$ from three steel bars, $\mathrm{T}_{400}$, can be measured. According to EFNARC (2002), when the ratio of $\mathrm{h}_{2}$ to $\mathrm{h}_{1}$ is larger than 0.8 , SCC has good passing ability. The measured values of $h_{2} / h_{1}$ are shown in tables 6 and 7.

\section{Experimental results}

\subsection{Fresh concrete results}

According to EFNARC (2002) standard, the flow diameter, time to flow a diameter of $50 \mathrm{~cm}$ ( $\mathrm{T}_{50}$ time), flow diameter after an hour, V-funnel flow time, V-funnel times delayed 5 min, Lbox ratio, air temperature and the unit weight of fresh concrete were measured for each mixture. The results of fresh concrete experiments obtained for the samples in I and II groups are given in tables 6 and 7 as follows.

The flow diameters of concrete containing fly ash and not containing fly ash were measured as $660-740 \mathrm{~mm}$ and $600-650 \mathrm{~mm}$ respectively. For all mixtures, as $\mathrm{w} /(\mathrm{c}+\mathrm{m})$ rate increases, flow diameter has increased because of shear stress and viscosity of concrete decreased. Fly ash replacing instead of cement has caused to the increase in the workability and flow diameter.

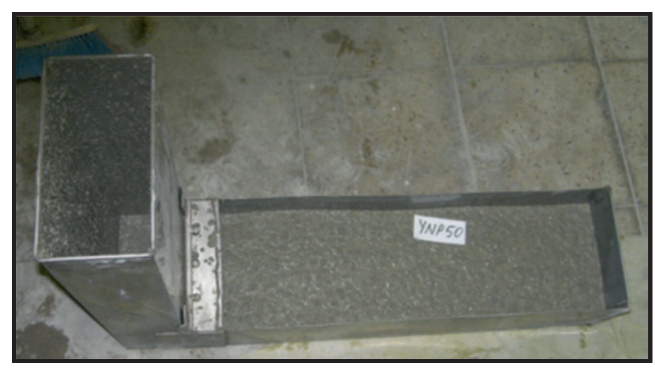

Figure 4. L-box test. 


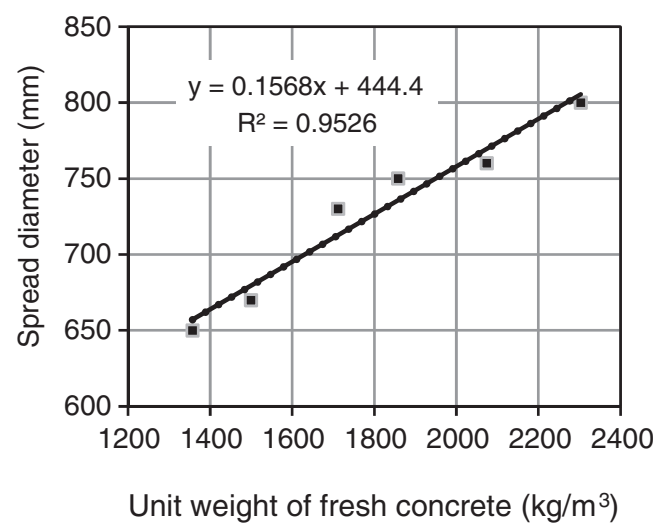

Figure 5. Effect of unit weight to flow diameter.

The flow diameter of concrete samples in I group has varied between 650 and $800 \mathrm{~mm}$ as seen in table 6. For this group, the relationships between flow diameter and unit weight of concrete are shown in figure 5. The mixtures have satisfied $650-800 \mathrm{~mm}$ value of flow diameter, proposed by EFNARC (2002). The results show that as density of SCLC increases, its workability increases too. This is a prospective result since the spread and placement properties of SCC are provided by its weight. Due to increasing weight of the mix, the spreading capability will be enhanced at the fresh stage. The times to flow a diameter of $50 \mathrm{~cm}$ was measured as $3-7 \mathrm{~s}$ and $2-8 \mathrm{~s}$ in the I and II groups of experiments, respectively. According to the results of Dowson (2002), the time to flow a diameter of $50 \mathrm{~cm}$ is not more than $3 \mathrm{~s}$. The EFNARC (2002) also suggested that the time to flow a diameter of $50 \mathrm{~cm}$ is $2-5 \mathrm{~s}$. The time to flow a diameter of $50 \mathrm{~cm}$ is related to flow rate and plastic viscosity of concrete. The shear stress and viscosity of fresh concrete decreased as the amount of water increased for all mixtures. Fly ash replacing instead of cement increased the flow rate of concrete. On condition that the $\mathrm{w} /(\mathrm{c}+\mathrm{m})$ rate and the type of mineral additive are constant, when pumice rate was increased in the aggregate, the time to flow a diameter of $50 \mathrm{~cm}$ had extended (figure 6).

The mineral additives slow the strength gain because of their low pozzolanic activity when the amount of mineral additive increased in the mixture. As a result, loss of workability has decreased generally as mineral additive and amount of water increased. The V-funnel flow times were measured as 7-14 s in the I group of experiments.

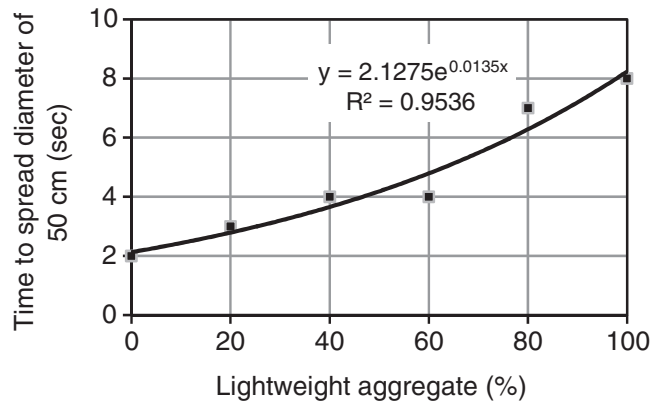

Figure 6. The relationship between lightweight aggregate ratio with time to flow a diameter of $50 \mathrm{~cm}$. 
Besides, in this group increasing fly ash rate also increased the passing ability of SCC. But, flow time was extended because of the segregation as the $w /(c+m)$ rate exceeds the optimum value. The V-funnel flow times were measured as 8-21 s in II group of experiments. The increasing lightweight aggregate rate, i.e. decrease of unit weight, extended the V-funnel flow time. For II group of experiments, the relationship between unit weight of fresh concrete and V-funnel flow time was given in figure 7.

Khurana \& Topçu (2000), for the flow times through V-funnel with $5 \times 5 \mathrm{~cm}$ span of SCC with different maximum grain size $\left(\mathrm{D}_{\max }\right)$, has suggested boundary values as follows: $8-12 \mathrm{~s}$ for $\mathrm{D}_{\max }=15 \mathrm{~mm}$, for $11-15 \mathrm{~s}$ for $\mathrm{D}_{\max }=20 \mathrm{~mm}$. The EFNARC (2002) committee also suggested that the V-funnel flow time becomes 6-12 s.

In this test, the exit time of concrete through orifice is measured. Extension of this time in SCLC is ordinary, since increasing weight of the mix enhanced the spreading capability at the fresh stage. Therefore, the V-funnel flow times on the amount of recommended values can be considered suitable for $\mathrm{V}$-funnel flow time. The difference of $\mathrm{V}$-funnel time delayed 5 min was 2-5 s in I group. The EFNARC (2002) Committee indicated that, if there is a difference of more than $3 \mathrm{~s}$ according to first flow time, there is the static segregation. It was seen that the flow time decreased in $w /(c+m)$ ratio $0.35-0.40$ mixtures, but flow time increased in $w /(c+m)$ ratio 0.45 mixtures as the amount of water increased. So, the static segregation risk increases since the viscosity of fresh concrete decreased as the amount of water increases on the optimum value in fresh concrete. As a result of this, V-funnel time, delayed 5 min, extends. Besides, the static stability of fresh concrete has increased and V-funnel time, delayed $5 \mathrm{~min}$, has been shortened since the viscosity of fresh concrete has increased without further increasing the shear stress of the fresh concrete as the amount of fly ash has increased. The V-funnel time, delayed 5 min, increased when the lightweight aggregate ratio increased as $w /(c+m)$ was constant. The blocking became in mixtures produced with the pumice aggregate of $100 \%$ and lack of air entraining admixture.

In the I group of experiments, L-box $\left(\mathrm{h}_{1} / \mathrm{h}_{2}\right)$ ratios were measured as $0.81-0.93$ and $0.77-$ 0.93 in the I and II groups of experiments, respectively. It was seen that the L-box $\left(\mathrm{h}_{1} / \mathrm{h}_{2}\right)$ ratio increased as the amount of fly ash and $w /(c+m)$ ratio increased for all mixtures. Besides, that increased when the amount of normal aggregates increased in all mixtures, i.e. the passing ability had increased as unit weight of fresh concrete increased. The relationship between L-box $\left(\mathrm{h}_{1} / \mathrm{h}_{2}\right)$ ratio and unit weight of fresh concrete in the II group was shown in figure 8.

So, the L-box $\left(\mathrm{h}_{1} / \mathrm{h}_{2}\right)$ ratio is equal to 1 (one) in a very fluid material. The report of the EFNARC (2002) committee indicated that if this ratio is smaller than 0.8 , there is a risk of

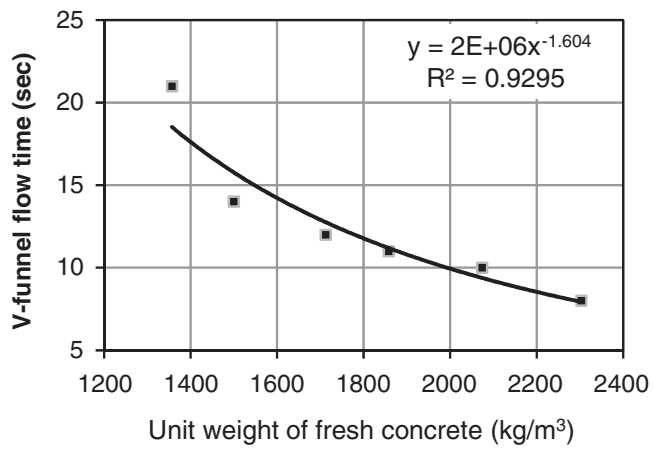

Figure 7. Effect of unit weight to V-funnel flow time. 


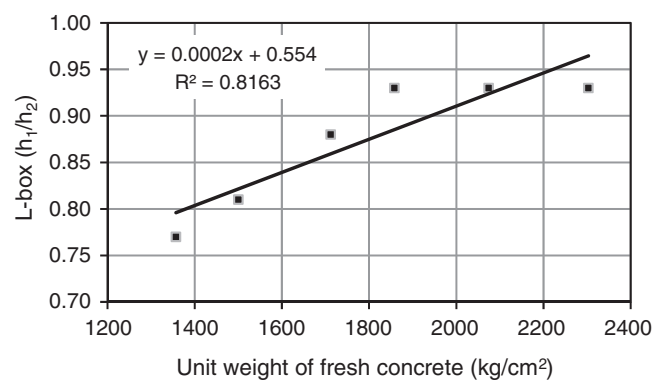

Figure 8. The relationship between L-box $\left(\mathrm{h}_{1} / \mathrm{h}_{2}\right)$ ratio and unit weight of fresh concrete in II Group.

aggregate being blocked. However, Bernabeu \& Laborde (2000) were reported that the mixtures of L-box ratio 0.65 (flow diameter of $60 \mathrm{~cm}$ ) easily filled the formwork, according to results of their experiments.

\subsection{Hardened concrete results}

The hardened concrete properties were examined separately for the I and II groups of experiments as in fresh concrete test results. The test results of dry unit weight, compressive strength for 7, 28, 90 and 180 days, splitting tensile strength for 28 days, thermal conductivity and ultrasonic pulse velocity (figure 9) were given in tables 8 and 9 for the I and II groups of specimens, respectively. The ultrasonic pulse velocities were measured by a pulse meter with an associated transducer pair. The transducer pair had a nominal frequency of $54 \mathrm{kHz}$. The principle of ultrasonic pulse velocities measurement involves sending a wave pulse into concrete and measuring the travel time for the pulse to propagate through the samples. The pulse is generated by a transmitter and received by a receiver. In the experimental studies, the transmitter and receiver were placed at the top and bottom surfaces of a cylindrical specimen, respectively. For each mixture, three samples of $100 \times 200 \mathrm{~mm}$ cylinders (totally 270 specimens) were prepared and cured in lime-saturated water at $20 \pm 3{ }^{\circ} \mathrm{C}$ until the testing time. At the testing age, the samples were tested for compressive strength, and splitting-tensile strength in accordance with ASTM C-192 and ASTM C-496, respectively.

In the I group, the dry unit weights of concrete samples were specified between 991-839 $\mathrm{kg} / \mathrm{m}^{3}$ and $1037-1014 \mathrm{~kg} / \mathrm{m}^{3}$ for those produced with lightweight aggregate of $100 \%$ and control samples not containing mineral additive. Although not a very big difference between them, replacing of fly ash instead of cement in mixture has reduced unit weight. Besides, the unit weights of concretes have reduced as $\mathrm{w} /(\mathrm{c}+\mathrm{m})$ ratio and amount of mineral additive increased in mixture. The reason of this situation is that the increase of the spaces in concrete structure with the increasing of $w /(c+m)$ ratio and mineral additives replaced instead of cement have lower specific gravity than cement.

The dry unit weights of mixtures in the II group were also found between 1187 and $2156 \mathrm{~kg} / \mathrm{m}^{3}$. In this group, the unit weight of concrete significantly decreased with the increasing lightweight aggregate ratio. Demirboğa et al (2001) indicated that depending on the production method of lightweight concretes and type of aggregate, the unit weight of lightweight concretes may vary between 1360 and $1840 \mathrm{~kg} / \mathrm{m}^{3}$ for structural lightweight concretes and 320-1120 $\mathrm{kg} / \mathrm{m}^{3}$ for heat insulating concretes.

The SCLC's produced with pumice $100 \%$ is lighter than normal concrete when the unit weight of normal concrete is considered to be around $2300 \mathrm{~kg} / \mathrm{m}^{3}$. Since, the unit weights of 
Table 8. The hardened concrete properties of samples.

\begin{tabular}{|c|c|c|c|c|c|c|c|c|c|}
\hline \multirow{2}{*}{$\begin{array}{l}\text { Mix } \\
\text { CS1 }\end{array}$} & \multicolumn{4}{|c|}{$\begin{array}{l}\text { Compressive strength } \\
\text { (MPa) } \\
\text { day } 28 \text { day } 90 \text { day } 180 \text { day }\end{array}$} & $\begin{array}{l}\text { STS } \\
(\mathrm{MPa}) \mathrm{w} \\
\end{array}$ & \multirow{2}{*}{$\begin{array}{c}\text { Dry unit } \\
\text { eight }\left(\mathrm{kg} / \mathrm{m}^{3}\right) \\
1037\end{array}$} & \multirow{2}{*}{$\begin{array}{l}\text { Water absorption T } \\
(\%) \\
12.62\end{array}$} & \multirow{2}{*}{$\begin{array}{l}\text { Thermal conductivity } \\
\text { (W/mk) } \\
0.613\end{array}$} & \multirow{2}{*}{$\begin{array}{r}\begin{array}{r}\mathrm{UPV} \\
(\mathrm{m} / \mathrm{s})\end{array} \\
2867\end{array}$} \\
\hline & 11.8 & 13.9 & 14.4 & 15.5 & 1.94 & & & & \\
\hline $\mathrm{CS} 2$ & 10.3 & 12.7 & 13.1 & 14.3 & 1.86 & 1028 & 14.38 & 0.598 & 2815 \\
\hline CS3 & 8.8 & 10.6 & 11.9 & 12.3 & 1.71 & 1014 & 16.03 & 0.545 & 2685 \\
\hline FA1 & 10.0 & 14.9 & 15.1 & 15.8 & 1.98 & 991 & 13.17 & 0.512 & 2898 \\
\hline FA2 & 8.0 & 12.2 & 13.1 & 14.5 & 1.80 & 954 & 16.88 & 0.439 & 2757 \\
\hline FA3 & 6.8 & 9.8 & 11.0 & 11.2 & 1.61 & 903 & 21.65 & 0.366 & 2662 \\
\hline FA4 & 9.4 & 14.6 & 15.6 & 16.4 & 1.96 & 972 & 14.28 & 0.497 & 2889 \\
\hline FA5 & 7.5 & 11.3 & 12.7 & 14.9 & 1.73 & 909 & 17.23 & 0.424 & 2737 \\
\hline FA6 & 6.4 & 9.4 & 11.1 & 11.5 & 1.58 & 873 & 23.10 & 0.344 & 2642 \\
\hline FA7 & 8.9 & 14.4 & 15.8 & 16.9 & 1.95 & 967 & 15.21 & 0.473 & 2833 \\
\hline FA8 & 7.2 & 10.7 & 13. 2 & 15.6 & 1.68 & 905 & 17.79 & 0.389 & 2692 \\
\hline FA9 & 6.1 & 9.2 & 11.2 & 11.7 & 1.57 & 839 & 24.51 & 0.321 & 2586 \\
\hline FANP100 & 14.0 & 19.9 & 21.4 & 22.3 & 1.82 & 1187 & 16.76 & 0.606 & 3022 \\
\hline FANP80 & 15.6 & 22.2 & 23.9 & 24.9 & 2.16 & 1392 & 12.78 & 0.629 & 3256 \\
\hline FANP60 & 18.7 & 26.7 & 28.7 & 29.9 & 2.24 & 1622 & 10.68 & 0.845 & 3549 \\
\hline FANP40 & 21.6 & 30.9 & 33.2 & 34.6 & 3.05 & 1780 & 8.58 & 1.078 & 3743 \\
\hline FANP20 & 25.3 & 36.1 & 38.8 & 40.4 & 3.37 & 1976 & 7.22 & 1.238 & 3994 \\
\hline FANP00 & 32.4 & 53.3 & 57.2 & 60.0 & 4.20 & 2156 & 5.65 & 1.508 & 4340 \\
\hline
\end{tabular}

all other mixtures except for mixtures containing normal aggregate $100 \%$ and $80 \%$ are lower than $1840 \mathrm{~kg} / \mathrm{m}^{3}$, these are incorporated into the class of structural lightweight concretes. The compressive strengths of concrete in the I group for 7, 28, 90 and 180 ages were found between 6.07-9.97, 9.20-14.86, 11.24-15.11 and 11.71-15.78 MPa, respectively as seen in table 8 . The changes of compressive strength depending on the age of concrete were given in figure 10 . The

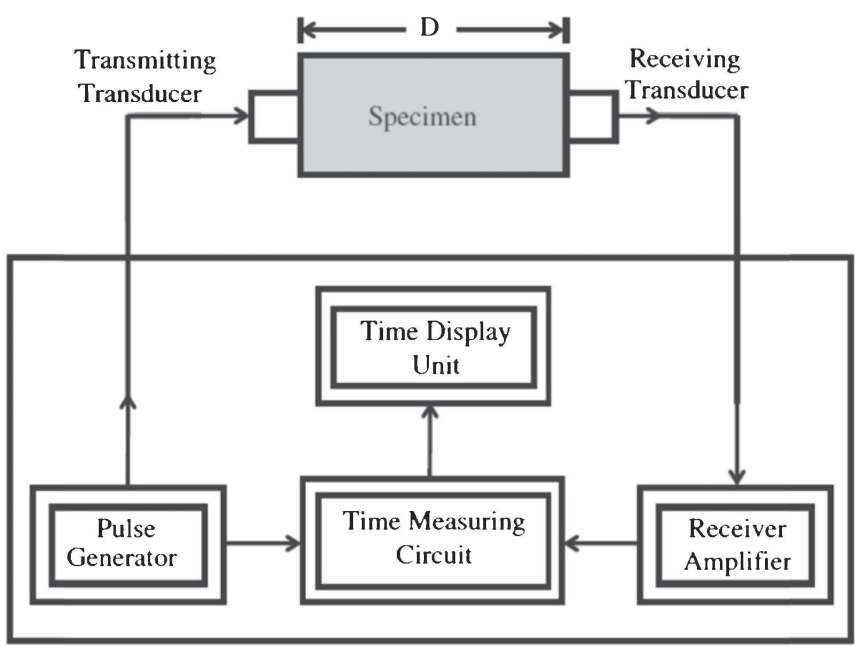

Figure 9. Schematic diagram of pulse velocity measurement. 
compressive strengths for 7, 28, 90 and 180 days in the II group of experiments were given in table 9.

The relationship between lightweight aggregate ratio and time-dependent compressive strength was also shown in figure 11. Generally, the compressive strengths of mixtures including fly ash for 7 and 28 days have stayed under control as samples not including mineral additive. This is because, mineral additive replaced instead of cement gained strength more slowly than cement. 90 and 180-day compressive strengths of mixtures including fly ash were approximate or higher values than control samples. Besides, the strength development was provided in low $\mathrm{w} /(\mathrm{c}+\mathrm{m})$ ratio because of the increase effect on the workability of fly ash.

The decrease of strength and unit weight with an increase of the amount of lightweight aggregate in mixture is explicit. In the I Group of experiments, when the ratio of lightweight aggregate was $20 \%$ in concrete mixture unit weight, and 28-day compressive strength decreased approximately $8 \%$ and $42 \%$, respectively. The water absorption values of concrete samples in I Group

Table 9. The water absorption and dry unit weight of mixtures.

\begin{tabular}{lccccccc}
\hline $\begin{array}{l}\text { Mixture } \\
\text { number }\end{array}$ & $\mathrm{w} /(\mathrm{c}+\mathrm{m})$ & $\begin{array}{c}\text { Mineral } \\
\text { additive } \\
(\%)\end{array}$ & $\begin{array}{c}\text { Dry weight } \\
(\mathrm{g})\end{array}$ & $\begin{array}{c}\text { Saturated } \\
\text { surface dry } \\
\text { weight }(\mathrm{gr})\end{array}$ & $\begin{array}{c}\text { Water } \\
\text { absorption by } \\
\text { weight }(\%)\end{array}$ & $\begin{array}{c}\text { Water } \\
\text { absorption by } \\
\text { volume }(\%)\end{array}$ & $\begin{array}{c}\text { Dry } \\
\text { unit weight } \\
\left(\mathrm{kg} / \mathrm{m}^{3}\right)\end{array}$ \\
\hline FA1 & 0.35 & 20 & 1605 & 1812 & 12.87 & 13.15 & 1022 \\
FA2 & 0.40 & 20 & 1566 & 1832 & 16.97 & 16.92 & 997 \\
FA3 & 0.45 & 20 & 1530 & 1839 & 20.18 & 19.66 & 974 \\
FA4 & 0.35 & 30 & 1582 & 1798 & 13.65 & 13.75 & 1007 \\
FA5 & 0.40 & 30 & 1549 & 1847 & 19.28 & 19.01 & 986 \\
FA6 & 0.45 & 30 & 1530 & 1844 & 20.52 & 19.99 & 974 \\
FA7 & 0.35 & 40 & 1572 & 1792 & 14.00 & 14.01 & 1001 \\
FA8 & 0.40 & 40 & 1543 & 1826 & 18.35 & 18.02 & 982 \\
FA9 & 0.45 & 40 & 1521 & 1846 & 21.39 & 20.71 & 968 \\
FANP00 & 0.30 & 0 & 3387 & 3578 & 5.65 & 12.18 & 2156 \\
FANP20 & 0.30 & 20 & 3104 & 3328 & 7.22 & 14.27 & 1976 \\
FANP40 & 0.30 & 40 & 2796 & 3036 & 8.58 & 15.28 & 1780 \\
FANP60 & 0.30 & 60 & 2548 & 2820 & 10.68 & 17.33 & 1622 \\
FANP80 & 0.30 & 80 & 2187 & 2466 & 12.78 & 17.79 & 1392 \\
FANP100 & 0.30 & 100 & 1865 & 2177 & 16.76 & 19.89 & 1187 \\
\hline
\end{tabular}

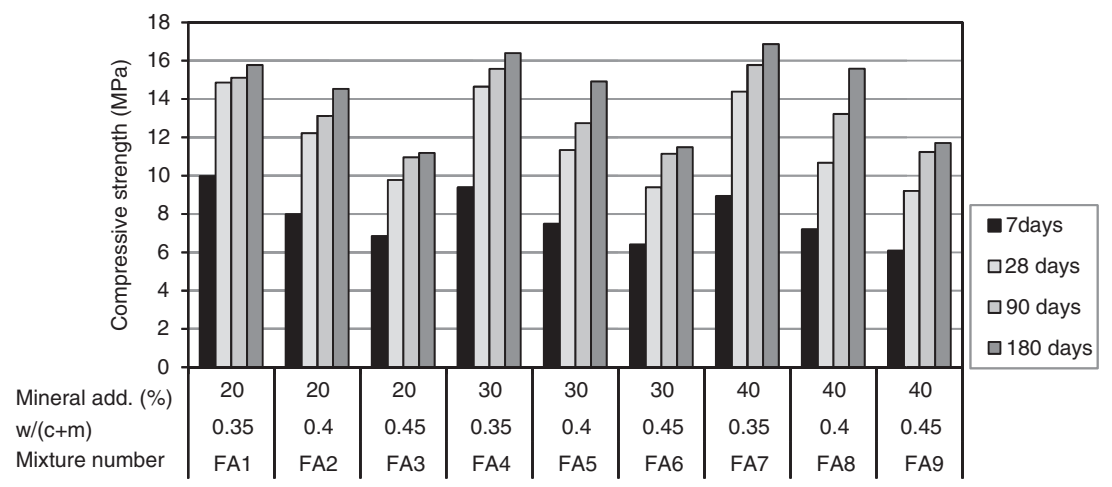

Figure 10. The time-dependent compressive strength of samples in I. 


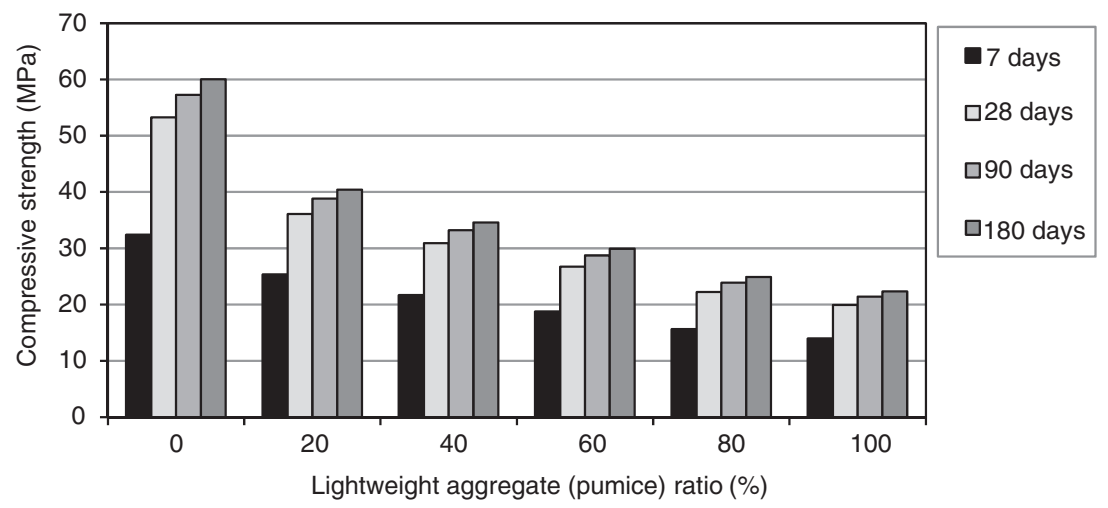

Figure 11. The relationship between lightweight aggregate ratio and compressive strength of II group.

and control samples were $13.17-24.51 \%$ and $12.62-16.03 \%$ by weight, respectively. Those were also specified 5.65-16.76\% for II Group of mixtures (table 9). The water absorption ratios of control samples not containing mineral additive had been less for the same $w /(c+m)$ ratio. Furthermore, the increase rate of mineral additive in the mixture also increased the water absorption ratios. The water absorption ratios of control samples not contained mineral additive had been less for the same $w /(c+m)$ ratio. Furthermore, the increase in the rate of water absorption was an expected result since the increase in the rate of lightweight aggregate in mixture caused to increase of volume of space in concrete.

The coefficients of thermal conductivity of SCLC in the I group and control samples were found as $0.321-0.512 \mathrm{~W} / \mathrm{mK}$ and $0.545-0.613 \mathrm{~W} / \mathrm{mK}$, respectively. The decrease of thermal conductivity was an expected result since the volume of space in concrete increased as the w/(c+m) ratio increased. Also, the thermal conductivity of mixtures decreased as rate of fly ash with lower unit weight than cement increased. The control samples not contained mineral additive had the higher thermal conductivity value for the same $w /(c+m)$ ratio. It was understood from all these results that thermal conductivity of SCLC is directly proportional with unit weight as in conventional concrete. This relationship was shown for the I group mixtures in figure 11.

The coefficients of thermal conductivity of SCLC in the II Group were also found as 0.606$1.508 \mathrm{~W} / \mathrm{mK}$. The factors affecting to the coefficient of thermal conductivity in the I Group of experiments also generated similar effects for the II Group of experiments. On the other hand, the increase in rate of lightweight aggregate decreased coefficient of thermal conductivity as expected. So, the unit weight and thermal conductivity decreased $8 \%$ and $18 \%, 17 \%$ and
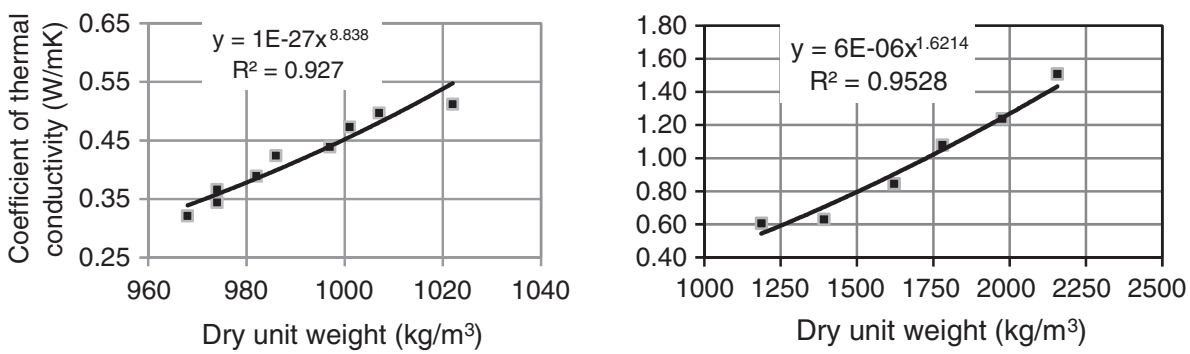

Figure 12. The relationship between thermal conductivity coefficient and dry unit weight. 

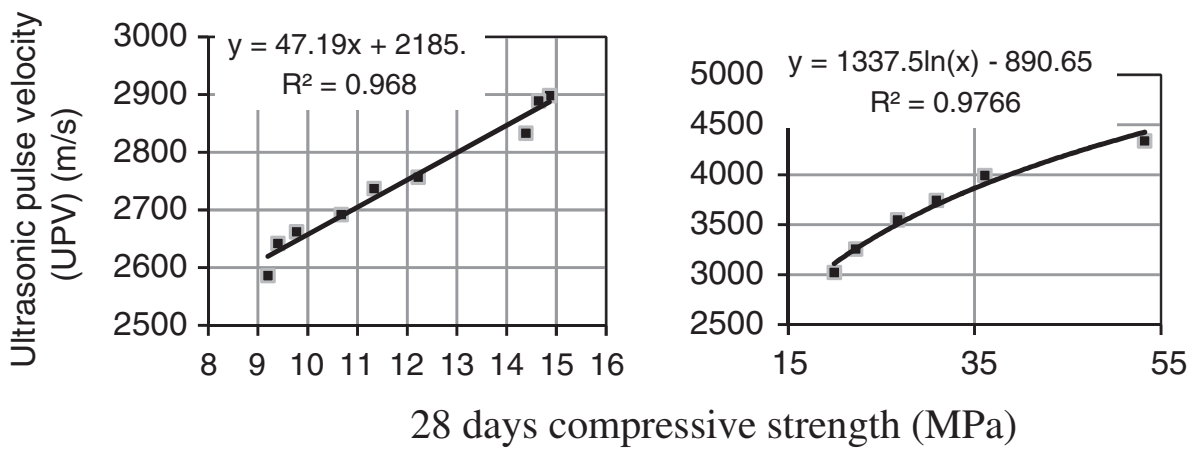

Figure 13. The ultrasonic pulse velocity and 28-day compressive strength of I and II group.

$29 \%, 45 \%$ and $60 \%$ when the lightweight aggregate ratios in mixture were $20 \%, 40 \%, 100 \%$, respectively. The changes in coefficients of thermal conductivity with the rate of lightweight aggregate and dry unit weight were shown in figure 12.

As a result, the path length of the ultrasonic pulse was the length of the specimen, which was measured by using a vernier with a minimum reading of $0.01 \mathrm{~mm}$. The ultrasonic pulse velocities of SCLC in the I and II group of experiments were found between 2586-2898 m/s and $3022-4770 \mathrm{~m} / \mathrm{s}$, respectively. The variables, affected to compressive strength also affected to ultrasonic pulse velocity. So, the ultrasonic pulse velocities also increased linearly with the increase in compressive strength.

The ultrasonic pulse velocities of samples in II Group also reduced significantly with the increase in amount of lightweight aggregate in mixture as in compressive strength. The relationship between ultrasonic pulse velocities and 28-day compressive strength of samples in the I and II groups were given in figure 13 .

\section{Conclusions}

Some results and recommendations that can be inferred from all of this experimental study are summarized below.

1. In all mixtures, the increase in the amount of fly ash improved the self-compatibility properties since that decreased the shear stress of concrete without increase viscosity excessively.

2. Because of the pumice and natural aggregate usage together in SCLC, the unit weight, thermal conductivity and ultrasonic pulse velocity values of concrete samples decreased while the compressive strengths and water absorption ratios increased with replacing fly ash instead of cement in the II group. But this reason is not related to the fly ash but the pumice ratio.

3. It was seen that the workability was also easier as density of SCLC increased. This was an expected result since the compacting and spreading properties of SCC were provided by its own weight.

4. The increase in the amount of fly ash retarded the bonding of water into mixture because of low pozzolanic activities of fly ash. As a result of this, the loss of workability decreased in general with the increase in the amount of fly ash and water. 
5. The increase of lightweight aggregate rate (i.e. decrease of density) increased the V-funnel flow time of SCC. There are two reasons for this. First, the flow time extends as unit weight decreases since the flow reason of concrete is that its own weight exceeds threshold stress. Therefore, the V-funnel flow time which was a little above the recommended value may be acceptable. The second, the increase in the amount of lightweight aggregate in mixture also increased the tendency to segregation of fresh concrete.

6. The flow test is not sufficient alone to determine the self-compatibility. While the spread and V-funnel tests are used in the control of flowability properties, L-box or U-box and V-funnel time delayed 5 min flowability should be used to specify the passing ability and resistance to segregation, respectively.

7. When the humidity control of aggregate was neglected and was not considered in concrete mix design, the significant fluctuations occurred in data of self-compactability tests. Therefore, especially grading and moisture content of pumice aggregate should be checked frequently and a quality entry plan with common-period must be created for this. Besides, the pumice aggregate should be stocked in closed storage areas and to be made provision for its properties not to change up to production stages.

8. The water absorption rate of lightweight aggregates is quite high. The continuance to adsorb the water of lightweight aggregate has affected the homogeneity of experiments during mixing and fresh concrete tests. Hence, the saturated lightweight aggregates should be used in future studies.

9. In the case of blended cement use in mixture, the type of mineral additives used in cement mixture should be determined and considered in the mixture account.

10. Firstly, the high-strength lightweight aggregates should be used as well to create a cement paste with well strength and high-performance should be generated to obtain high-strengths in SCLC.

11. It was determined that the percentage of entrained air is very important to avoid the segregation problems. Despite that the smaller amount of air is entrained, the production of mixture not to generate the segregation problems will enable the production of concrete with higher hardened concrete properties.

12. In future studies, the adequacy of adherence with reinforcement, shrinkage conditions and durability properties of SCLC should be investigated. Besides, the lightweight aggregate and normal aggregate combinations that would lead to maximum compacting, and less segregation may be investigated to leave the minimum air void in design of SCLC.

\section{References}

Aydın A C 2007 Self compactability of high volume hybrid fiber reinforced concrete. Construction Build. Mater. 21: 1146-1151

Aydın A C and Gül R 2007 Influence of volcanic originated natural materials as additives on the setting time and some mechanical properties of concrete. Construction Build. Mater. 21: 1274-1278

Aydın A C, Tortum A and Yavuz M 2006 Prediction of concrete elastic modulus using adaptive neuro-fuzzy inference system. Civil Eng. Environ. Syst. 23: 295-309

Aydın A C, Arslan A and Gül R 2007 Mesoscale simulation of cement based materials' time dependent behavior. Computational Mater. Sci. 41(1): 20-26

Aydın A C, Düzgün O A and Tortum A 2008 Determination of the optimum conditions for steel fibers on the mechanical properties of natural lightweight aggregate concrete. Pollack Perodika 3(1): 101-112

Aydın A C, Karakoç M B, Düzgün O A and Bayraktutan M S 2010 Effect of low quality aggregates on the mechanical properties of lightweight concrete. Sci. Res. Essays 5(10): 1133-1140 
Bernabeu M and Laborde 2000 Brite Euram Project: Rational production and improved working environment through using self compacting concrete. Final report: Task 8.3 production system for civil engineering, Gtm construction

Boukendakdji O, Kenai S, Kadri E H and Rouis F 2009 Effect of slag on the rheology of fresh selfcompacted concrete. Construction Build. Mater. 23: 2593-2598

Demirboğa R, Örüng İ and Gül R 2001 Effects of expanded perlite aggregate and mineral admixtures on the compressive strength of low-density concretes. Cement Concrete Res. 31: 1627-1632

Dowson A J 2002 The application, self-compacting concrete (SCC) in precast products. BIBM $17^{\text {th }}$ International Congress of the Precast Concrete Industry, 2002, Istanbul (Turkey), 425-472

Düzgün O A, Gül R and Aydın A C 2005 Effect of steel fibers on the mechanical properties of natural lightweight aggregate concrete. Mater. Lett. 59: 3357-3363

EFNARC 2002 Specifications and guidelines for self-compacting concrete. EFNARC, Association House, 99 West Street, Farnham, UK, www.efnarc.org, ISBN 0 953973344, 32pp

Gül R, Okuyucu E, Türkmen İ and Aydın A C 2007 Thermo-mechanıcal propertıes of fiber reınforced raw perlite concrete. Mater. Lett. 61(29): 5145-5149

Haist M, Mechtcherine V, Beitzel H and Müller H S 2003 Retrofitting of building structures using pumpable self-compacting lightweight concrete. Proceedings of the 3rd international symposium on self-compacting concrete, RILEM Publications, Reykjavik, 776-785

Hasar U C, Akkaya G, Aktan M, Gozu C and Aydın A C 2009 Water-to-cement ratio prediction using ANNs from non-destructive and contactless microwave measurements. Progr. Electromag. Res. PIER 94: $311-325$

Hasar U C, Simsek O and Aydın A C 2010 Application of varying-frequency amplitude-only technique for electrical characterization of hardened cement-based materials. Microwave Opt. Technol. Lett. 52(4): 801-805

Khatib J M 2008 Performance of self-compacting concrete containing fly ash. Construction Build. Mater. 22: 1963-1971

Khurana R and Topçu O 2000 Role of Superplasticizers in the development of self-compacting concrete. Second international symposium on cement and conc. tech. in the 2000s, vol. I, Istanbul, Turkey, 473-482

Kotan T and Gül R 2010 Effect of atmospheric pressure steam curing to mechanical properties of lightweight concrete produced with Erzurum-Pasinler pumice. Mach. Technol. Mater. Int. Virtual J. 4-5: 66-69

Kurt M 2009 Investigation of physical and mechanical properties of self-compacting lightweight concrete. Ph.D. thesis, Atatürk University Graduate School of Natural and Applied Sciences, 195

Oğuz E and Aydın A C 2003 Prediction of adsorption velocity of phosphate removal from wastewater with gas concrete, including PH, temperature, and agitation speed. Int. J. Environ. Pollution 19: 603-614

Siddique R 2011 Properties of self-compacting concrete containing class F fly ash. Mater. Des. 32: 15011507

Sukumar B, Nagamani K and Srinivasa Raghavan R 2008 Evaluation of strength at early ages of selfcompacting concrete with high volume fly ash. Construction Build Mater. 22: 1394-1401

Tortum A, Celik C and Aydın A C 2005 Determination of the optimum conditions for tire rubber in asphalt concrete. Build. Environ. 40: 1492-1504

Turkmen İ, Öz A and Aydın A C 2010 Characteristics of workability, strength, and ultrasonic pulse velocity of SCC containing zeolite and slag. Sci. Res. Essays 5(15): 2055-2064

Wua Z, Zhang Y, Zheng J and Ding Y 2009 An experimental study on the workability of self-compacting lightweight concrete. Construction Build. Mater. 23: 2087-2092 